\title{
Deep Sylvian Meningioma: A Case Report and Review of the Literature
}

\author{
Nidhal Matar ${ }^{1}$ Kais Maamri ${ }^{1} \quad$ Adnene Boubaker $^{1} \quad$ Jalel Kallel $^{1}$ Hafedh Jemel $^{1}$ \\ ${ }^{1}$ Department of Neurological Surgery, Institut National de \\ Neurologie, Tunis, Tunisia \\ Address for correspondence Nidhal Matar, MD, Institut National de \\ Neurologie, Tunis, Tunisia (e-mail: matarnidhal2007@yahoo.fr). \\ Indian J Neurosurg 2016;5:172-175.
}

\begin{abstract}
Keywords

- meningioma

- sylvian

- dural attachment
\end{abstract}

\section{Introduction}

Meningiomas are extra-axial tumors deriving from the arachnoid cap or meningothelial cells. They usually display a dural attachment. Whereas, meningiomas without dural attachment, are extremely rare and reported only occasionally in the literature. In this paper, the authors present a new case of deep sylvian meningioma and briefly review the relevant literature.

\section{Case Report}

A 39-year-old man presented at hospital with a 1-month history of headache associated with only one episode of generalized tonic-clonic seizure. Neurological examination showed no abnormality. Computing tomography (CT) of the brain revealed an isodense mass lesion in the right temporofrontal region with homogeneous enhancement. Magnetic resonance imaging (MRI) demonstrated a $50 \times 40 \mathrm{~mm}$ mass lesion which was isointense on T1- ( - Fig. 1) and hypointense on T2-weighted images (-Fig. 2), with an homogeneous enhancement after gadolinium administration. A small cystic lesion was adjacent to the interior pole of the tumor. Coronal, axial, and sagittal MRI (-Fig. 3) revealed no dural attachment. The mass appeared to be mainly located near the deep right sylvian fissure. The tumor caused peritumoral white matter edema. The first diagnosis was brain metastasis.

The patient underwent a right fronto-pterional craniotomy. The dura and cortical surface appeared intact. Through a cortical incision, a brown tumor was reached $\sim 1.5 \mathrm{~cm}$ below the surface. It was a solid mass and well demarcated from normal parenchyma. However, inferior pole of the tumor was received

February 11, 2016

accepted

May 18, 2016

published online

December 5, 2016
DOI http://dx.doi.org/

10.1055/s-0036-1585458. ISSN 2277-954X. (c) 2016 Neurological Surgeons' Society of India
License terms

(๑) $\odot \circledast$ 


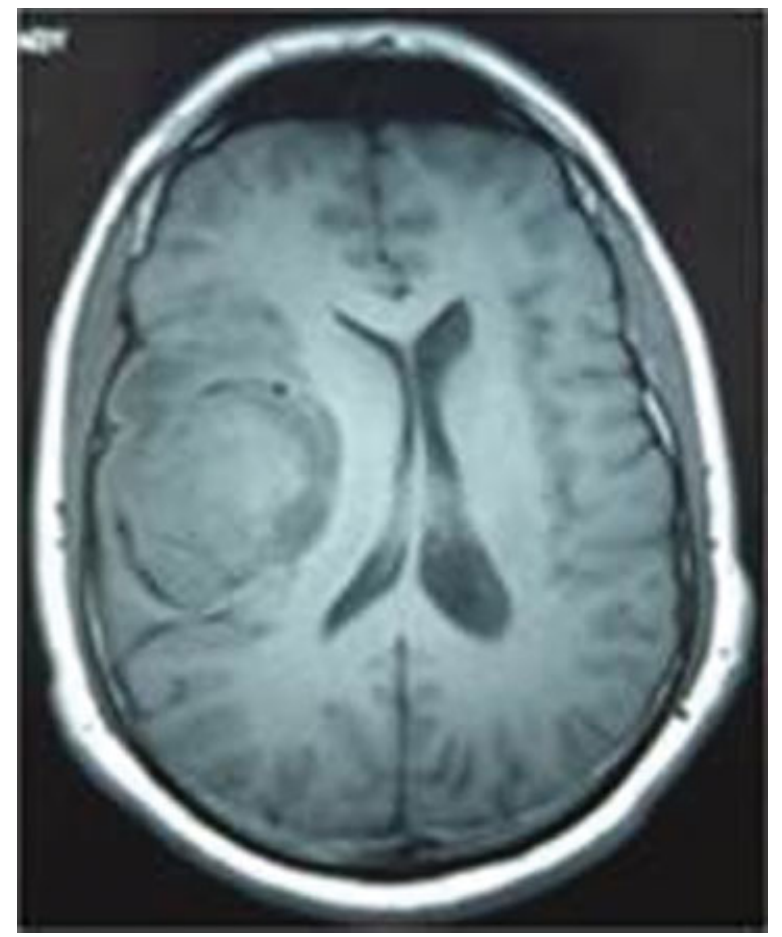

Fig. 1 Axial T1-weighted image reveals a well-defined mass that is isointense with the brain.

firmly adherent to the superior division of the middle cerebral artery and contained numerous perforators. The cyst contained xanthochromic fluid. The tumor was dissected carefully and removed totally. The postoperative course was uneventful and the patient was discharged without any neurodeficit.

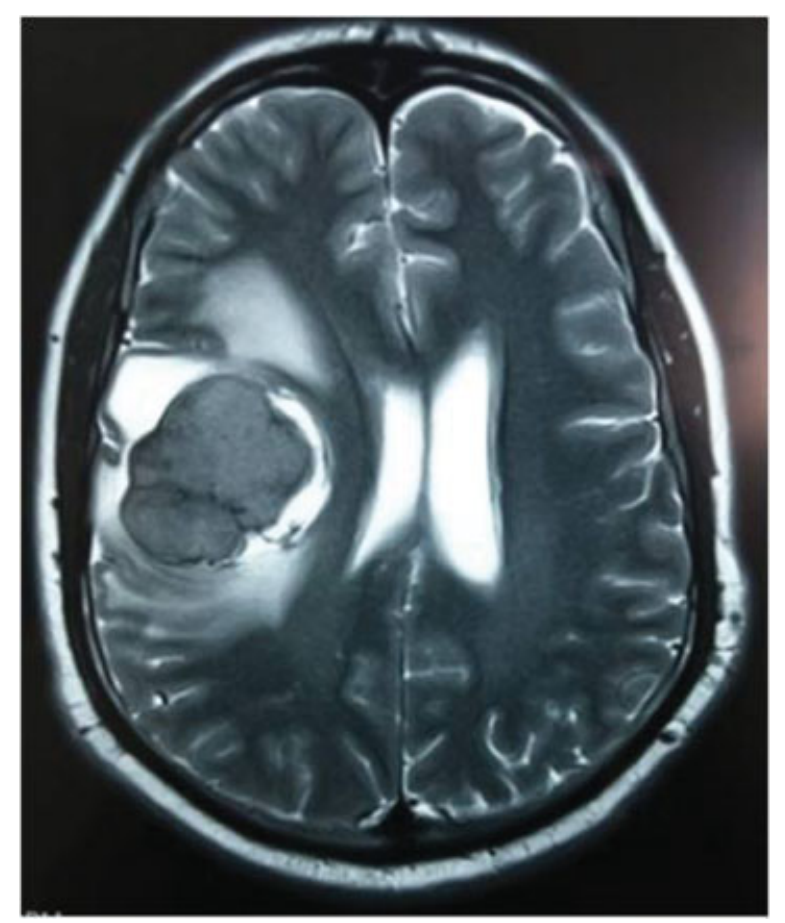

Fig. 2 Axial T2-weighted axial image reveals an iso-hypointense mass with marked peritumoral edema.
The histological examination revealed a tumor tissue composed of meningeal cells arranged in whorls and interesting beams, mitoses were rare and there was no necrosis. Immunohistochemical findings showed that the tumor cells were positive for vimentin and focally positive for epithelial membrane antigen. On the basis of these findings, it was concluded that the tumor was a World Health Organization (WHO) grade I meningioma of transitional type. Ten months after surgery, upon checkup, brain MRI showed no recurrence of the tumor.

\section{Discussion}

Meningiomas arise from meningothelial cells that line the arachnoid membrane, hence most of them are dural-based lesions and commonly located along the falx, tentorium, sphenoid bone, or over the convexity. Meningiomas without direct contact to the dura mater have been scarcely described. Cushing and Eisenhardt ${ }^{1}$ first recognized and described these tumors using the term "meningiomas without dural attachment," and classified them into five varieties: intraventricular, pineal region, deep sylvian, intraparenchymal or subcortical, and others.

Deep sylvian meningiomas are a very rare entity. ${ }^{2}$ To our knowledge, including the present case, only 27 cases are reported in the international literature ( - Table 1 ). According to some authors, these meningiomas probably arise from arachnoid cap cells that are found in the VirchowRobin spaces along the cerebral vasculature. ${ }^{3}$

By reviewing the literature, these meningiomas occur mainly in young adults with a middle age around 26.5 years (8 cases were aged less than 14 years). There is a significant male predominance especially in the pediatric cases (pediatric sex ratio, 7/1). This epidemiological description seems in sharp contrast with the well-known middle-aged female prevalence of the "classic" meningioma. Clinically, the majority of patients presented with seizure (20 cases). Three patients complained from motor weakness, and six others from headache.

On MR imaging, there were the same characteristics as for "classic meningioma": isointense T1, hyperintense T2, and homogenous enhancement with gadolinium, but without any dural attachment and totally surrounded by brain parenchyma. When reported, peritumoral edema is described as severe or moderate in most patients. Calcifications are rarely described and there is only one patient with an intratumoral hemorrhage.

On histopathological examination, twenty-one were WHO grade I, two WHO grade II, and two WHO grade III. Psammomatous and transitional types are the most common (16 cases). Prognostic factors are the same as for the other types of meningioma. They basically depend on the histological grade, quality of resection, and the importance of vessels sacrifice.

\section{Conclusion}

Deep sylvian meningiomas are a rare entity. Preoperative diagnosis is difficult considering the rarity and the similarity of imaging findings to other more common intra-axial lesions. 

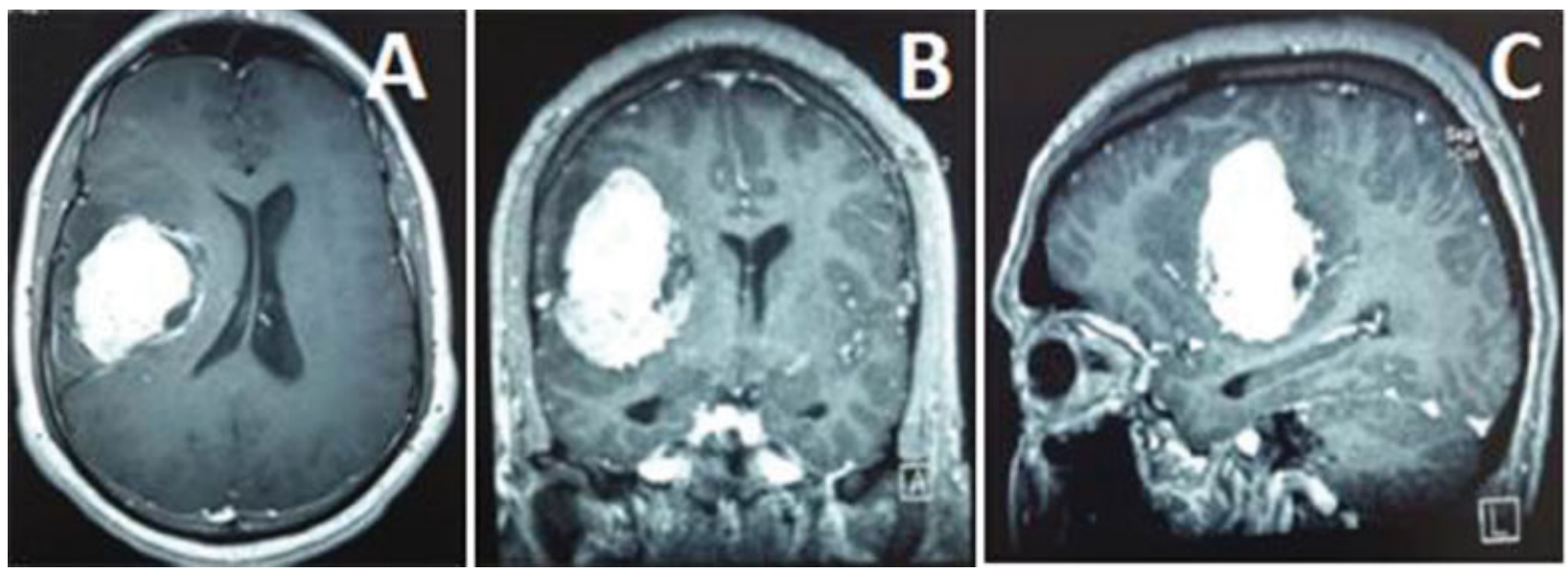

Fig. 3 T1-weighted images with gadolinium demonstrating the homogenously enhanced tumor without dural attachment: Axial (A), Coronal (B), and sagittal (C).

Table 1 Reported cases of deep sylvian meningiomas

\begin{tabular}{|c|c|c|c|c|}
\hline Authors (year) & Age & Sex & Clinical presentation & Tissue type \\
\hline Cushing et al (1938) ${ }^{1}$ & $\begin{array}{l}8 y \\
48 y\end{array}$ & $\begin{array}{l}M \\
F\end{array}$ & $\begin{array}{l}\text { Seizures } \\
\text { Seizures }\end{array}$ & $\begin{array}{l}\text { Psammomatous } \\
\text { Psammomatous }\end{array}$ \\
\hline Barcia-Goyanes et al $(1953)^{4}$ & $20 y$ & $\mathrm{~F}$ & Seizures & Psammomatous \\
\hline Mori et al $(1977)^{5}$ & 23 y & $\mathrm{M}$ & Seizures & Transitional \\
\hline Saito et al $(1979)^{6}$ & $31 \mathrm{y}$ & $\mathrm{F}$ & Seizures & Psammomatous \\
\hline Tsuchida et al $(1981)^{7}$ & $46 y$ & M & Headache & Meningotheliomatous \\
\hline Okamoto et al $(1985)^{8}$ & $\begin{array}{l}27 y \\
35 y\end{array}$ & $\begin{array}{l}F \\
F\end{array}$ & $\begin{array}{l}\text { Headache } \\
\text { Seizures }\end{array}$ & $\begin{array}{l}\text { Fibroblastic } \\
\text { Fibroblastic }\end{array}$ \\
\hline Hirao et al $(1986)^{9}$ & 34 y & $\mathrm{F}$ & Seizures & Fibroblastic \\
\hline Silbergeld et al (1988) & $4 \mathrm{y}$ & $\mathrm{F}$ & Seizures & Meningotheliomatous \\
\hline Drake et al $(1986)^{11}$ & $3 y$ & M & Headache & Malignant \\
\hline Cho et al $(1990)^{12}$ & $2 y$ & M & $\begin{array}{l}\text { Seizures, } \\
\text { hemiparesis }\end{array}$ & Transitional \\
\hline Graziani et al (1992) ${ }^{13}$ & $19 y$ & $\mathrm{M}$ & $\begin{array}{l}\text { Headache, } \\
\text { hemiparesis }\end{array}$ & Psammomatous \\
\hline Mori et al $(1994)^{14}$ & $12 \mathrm{y}$ & $\mathrm{M}$ & Headache & Transitional \\
\hline Chiocca et al (1994) ${ }^{15}$ & 26 y & $\mathrm{F}$ & Seizures & Fibroblastic \\
\hline Matsumoto et al (1997) ${ }^{16}$ & $62 \mathrm{y}$ & $\mathrm{F}$ & Seizures & Psammomatous \\
\hline Cooper et al (1997) ${ }^{17}$ & 62 y & $\mathrm{F}$ & Seizures & Transitional \\
\hline Mitsuyama et al $(2000)^{18}$ & $20 \mathrm{mo}$ & & Seizures & Fibroblastic \\
\hline Kaplan et al (2002) & $11 \mathrm{y}$ & $\mathrm{M}$ & Seizures & Atypical \\
\hline Chang et al (2005) ${ }^{20}$ & 35 y & $\mathrm{M}$ & Seizures & Transitional \\
\hline Mclver et al $2005^{21}$ & 23 y & $\mathrm{M}$ & Seizures & Chordoid \\
\hline Eghwrudjakpor et al (2006) 22 & $73 y$ & $\mathrm{~F}$ & NS & NS \\
\hline Samson et al $(2009)^{2}$ & $6 y$ & $\mathrm{M}$ & Seizures & WHO G I \\
\hline Cecchi et al $(2009)^{3}$ & 23 y & $\mathrm{M}$ & $\begin{array}{l}\text { Headache, } \\
\text { hemiparesis }\end{array}$ & Atypical \\
\hline Miyahara et al $(2011)^{23}$ & $34 \mathrm{y}$ & $\mathrm{F}$ & Seizures & Transitional \\
\hline Fukushima et al $(2014)^{24}$ & $10 y$ & $\mathrm{M}$ & Seizures & Sclerosing \\
\hline Our case & 39 y & $\mathrm{M}$ & Seizures & Transitional \\
\hline
\end{tabular}

Abbreviations: F, female; G, grade; M, male; NS, not stated; WHO, World Health Organization. 
Nevertheless, neurosurgeons and neuropathologists should be aware of this possibility and should include this hypothesis in the differential diagnosis of an intraparenchymal tumor.

\section{References}

1 Cushing H, Eisenhardt L. Meningiomas: Their classifications, regional behaviour, live history and surgical results. Charles $C$ Thomas: Springfield; 1938:133-165

2 Samson Sujit Kumar G, Rajshekhar V. Deep sylvian meningioma: a case report and review of literature. Childs Nerv Syst 2009; 25(1):129-132

3 Cecchi PC, Campello M, Rizzo P, Mair K, Schwarz A. Atypical meningioma of the sylvian fissure. J Clin Neurosci 2009;16(9): 1234-1239

4 Barcia-Goyanes JJ, Calvo-Garra W. Meningiomas without dural attachment. Acta Neurochir (Wien) 1953;3:241-247

5 Mori S, Ishihara H, Sogabe T, Kodama Y, Hibino H. A case of deep sylvian meningioma (author's transl) [in Japanese]. No Shinkei Geka 1977;5(4):385-392

6 Saito A, Mizuno Y, Adachi Y, Itoh T. Deep Sylvian psammomeningioma, report of a case (author's transl) [in Japanese]. No To Shinkei 1979;31(1):79-83

7 Tsuchida T, Ito J, Sekiguchi K, Honda H, Ueki K. A case of deep sylvian meningioma with intracerebral hematoma (author's transl) [in Japanese]. No Shinkei Geka 1981;9(3):395-400

8 Okamoto S, Handa H, Yamashita J, Tokuriki Y. Deep sylvian meningiomas. Surg Neurol 1985;23(3):303-308

9 Hirao M, Oka N, Hirashima Y, Horie Y, Takaku A. Deep sylvian meningioma: case report and review of the literature [in Japanese]. No Shinkei Geka 1986;14(12):1471-1478

10 Silbergeld D, Berger M, Griffin B. Sylvian fissure meningioma in a child: case report and review of the literature. Pediatr Neurosci 1988;14(1):50-53

11 Drake JM, Hendrick EB, Becker LE, Chuang SH, Hoffman HJ, Humphreys RP. Intracranial meningiomas in children. Pediatr Neurosci 1985-198612(3):134-139
12 Cho BK, Wang KC, Chang KH, Chi JG. Deep sylvian meningioma in a child. Childs Nerv Syst 1990;6(4):228-230

13 Graziani N, Donnet A, Vincentelli F, Dechambenoit G, Grisoli F. Deep sylvian meningioma. Apropos of a case. Review of the literature [in French]. Neurochirurgie 1992;38(3):179-182

14 Mori Y, Shibuya M, Sugita K, Nagasaka T. Deep sylvian meningioma: a case report of a child [in Japanese]. No Shinkei Geka 1994;22(12):1147-1151

15 Chiocca EA, Boviatsis EJ, Westmark RM, Short MP, Richardson EP, Zervas NT. Deep sylvian fissure meningioma without dural attachment in an adult: case report. Neurosurgery 1994;35(5): 944-946, discussion 946

16 Matsumoto S, Yamamoto T, Ban S, et al. A case of deep sylvian meningioma presenting temporal lobe epilepsy [in Japanese]. No To Shinkei 1995;47(5):503-508

17 Cooper JR, Marshman LA, Smith CM, Powell T. Case report: sylvian fissure meningioma without dural attachment in a 4-year-old child. Clin Radiol 1997;52(11):874-876

18 Mitsuyama T, Kasuya H, Kubo O, Hirasawa K, Hori T. Left Sylvian fissure meningioma in a one-year-eight-month old child [in Japanese]. No Shinkei Geka 2000;28(5):459-464

19 Kaplan SS, Ojemann JG, Park TS. Pediatric sylvian fissure meningioma. Pediatr Neurosurg 2002;36(5):275-276

20 Chang JH, Kim JA, Chang JW, Park YG, Kim TS. Sylvian meningioma without dural attachment in an adult. J Neurooncol 2005;74(1):43-45

21 Mclver JI, Scheithauer BW, Atkinson JL. Deep sylvian fissure chordoid meningioma: case report. Neurosurgery 2005;57(5): E1064, discussion E1064

22 Eghwrudjakpor PO, Mori K. Sylvian cleft meningioma: surgical approach and postoperative morbidity. Niger J Med 2006;15(4): 437-440

23 Miyahara K, Ichikawa T, Yagishita S, et al. Deep sylvian meningioma without dural attachment: a case report [in Japanese]. No Shinkei Geka 2011;39(11):1067-1072

24 Fukushima S, Narita Y, Yonezawa M, et al. Short communication: sclerosing meningioma in the deep sylvian fissure. Brain Tumor Pathol 2014;31(4):289-292 